BLUE-CHIP BLACK 


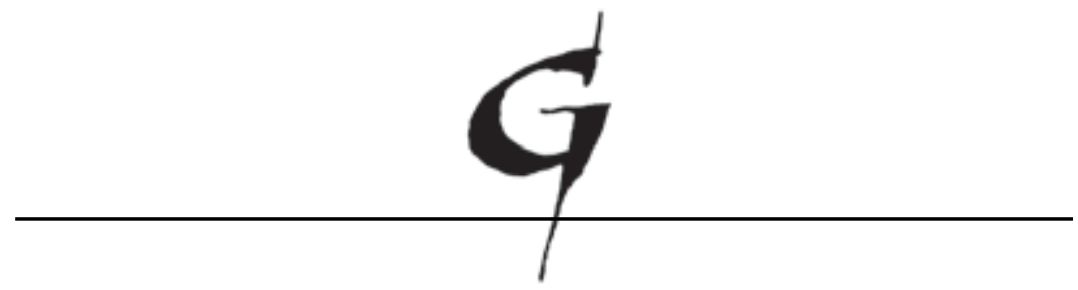

THE GEORGE GUND FOUNDATION IMPRINT IN AFRICAN AMERICAN STUDIES

The George Gund Foundation has endowed this imprint to advance understanding of the history, culture, and current issues of African Americans. 


\section{Blue-Chip Black}

Race, Class, and Status in the New

Black Middle Class

KARYN R. LACY

뚜

UNIVERSITY OF CALIFORNIA PRESS Berkeley Los Angeles London 
University of California Press, one of the most distinguished university presses in the United States, enriches lives around the world by advancing scholarship in the humanities, social sciences, and natural sciences. Its activities are supported by the UC Press Foundation and by philanthropic contributions from individuals and institutions. For more information, visit www.ucpress.edu.

A portion of chapter 5 appeared previously in "Black Spaces, Black Places: Strategic Assimilation and Identity Construction in Middle-Class Suburbia," Ethnic and Racial Studies 27, no. 6 (2004): 908-30, http://www.tandf.co.uk/journals. Portions of the book also appeared earlier in "A Part of the Neighborhood?': Negotiating Race in American Suburbs," International Journal of Sociology and Public Policy 22 (2002): 39-74, http:/www.emeraldinsight.com/info/ journals/ijssp/notes.jsp.

University of California Press

Berkeley and Los Angeles, California

University of California Press, Ltd.

London, England

(C) 2007 by The Regents of the University of California

Library of Congress Cataloging-in-Publication Data

Lacy, Karyn, [date-].

Blue-chip Black : race, class, and status in the new Black middle class / Karyn Lacy.

p. $\mathrm{cm}$.

Includes bibliographical references and index.

ISBN: 978-0-520-25 I I 5-I (cloth : alk. paper) ISBN: 978-0-520-25II6-8 (pbk. : alk. paper)

I. African Americans-Social conditions-1975-

Case studies. 2. African Americans-Race identityCase studies. 3. Middle class-United States-Case studies. 4. Social status-United States-Case studies. 5. United States-Race relations-Case studies. 6. African Americans-Washington Region-Social conditions. 7. African Americans-Race identityWashington Region. 8. Middle class-Washington Region. 9. Social status-Washington Region. Io. Washington Region—Race relations. I. Title.

EI 85.86.L $325 \quad 2007$

$305.896^{\prime} 0730722-\mathrm{dc22} \quad 2006025496$

Manufactured in the United States of America

$\begin{array}{lllllllll}\text { I } 5 & \text { I4 } & \text { I3 } & \text { I2 } & \text { II } & \text { IO } & 09 & 08 & 07\end{array}$

IO $\quad 9 \begin{array}{lllllllll} & 8 & 7 & 6 & 5 & 4 & 3 & 2 & \text { I }\end{array}$

This book is printed on New Leaf EcoBook 50, a I00\% recycled fiber of which $50 \%$ is de-inked postconsumer waste, processed chlorine-free. EcoBook 50 is acid-free and meets the minimum requirements of ANSI/ASTM D5634-OI (Permanence of Paper). 
To Leanita McClain

May you find rest for your soul 
